\title{
The prospective study of laparoscopic finding in infertility cases
}

\author{
Shruti*, Sangeeta Sen
}

Department of Obstetrics and Gynaecology, RNT Medical College, Udaipur, Rajasthan, India

Received: 08 April 2019

Accepted: 08 May 2019

\section{*Correspondence:}

Dr. Shruti,

E-mail: shruti2011c@gmail.com

Copyright: (C) the author(s), publisher and licensee Medip Academy. This is an open-access article distributed under the terms of the Creative Commons Attribution Non-Commercial License, which permits unrestricted non-commercial use, distribution, and reproduction in any medium, provided the original work is properly cited.

\section{ABSTRACT}

Background: Infertility is a global reproductive health issue that affects many individuals and family. The aim of the present study was to evaluate the laparoscopic finding in infertility cases.

Methods: Present study is a prospective study on laparoscopic evaluation of female infertility at Panna Dhai Mahila Chikitsalaya, Udaipur, Rajasthan, India. This study was done for the duration of one year from January 2017 to December 2017. Present study included total 100 cases randomly selected attending OBG OPD with both primary and secondary infertility.

Results: Out of 100 cases infertile women 62 cases $(62 \%)$ were of primary infertility and 38 cases $(38 \%)$ were of secondary infertility. The mean duration of infertility was 3.7 years. Laparoscopic finding were as follow $42 \%$ had polycystic ovaries, 33\% women had tubal pathology diagnosed on laparoscopy in which 22 women had tubal blocks diagnosed on chromopertubation and among them 19 had cornual block and 3 had ampullary block,11\% uterine finding and 7 women had adhesions in the pouch of douglas and one women had obliterated. About 20 women (20\%) conceived during the period of study. Seven women had post laparoscopic complication two women complained of shoulder pain and another four of abdominal pain post operatively.

Conclusions: Laparoscopy is the gold standard for diagnosing tubal factors, peritoneal factors, endometriosis and adhesions, because no other imaging technique provides the same degree of sensitivity and specificity and it should be considered in infertility workup for early treatment decision.

Keywords: Infertility, Laparoscopy, Laparoscopic finding, Primary infertility, Secondary infertility

\section{INTRODUCTION}

One of the most important and underappreciated reproductive health problems in developing countries is the high rate of infertility and childlessness. The inability to procreate is frequently considered a personal tragedy and a curse for the couple, impacting on the entire family and even the local community. Negative psychosocial consequences of childlessness are common and often severe. ${ }^{1}$

Infertility is a common problem in day to day practice and it still continues to baffle the gynaecologist. Being infertile or barren is the biggest social stigma faced by Indian women.

Infertility is the failure to conceive (regardless of cause) after 1 year of unprotected intercourse. Infertility affects approximately $10-15 \%$ of reproductive-aged couples. ${ }^{2}$ Its overall prevalence has been stable during the past 50 years; however, a shift in etiology and patient age has occurred. As the woman's age increases, the incidence of infertility also increases.

The common factors responsible for infertility in female are tubal factors, anovulatory disorder, endometriosis, uterine and cervical factors. ${ }^{3}$ An accurate diagnosis the 
key to successful treatment. The evaluation of the female partner begins with history and examination. It is more important to do first routine simple least invasive and predictive investigations for infertility.

Laparoscopy is the gold standard for diagnosis of tubal and peritoneal disease, endometriosis and adhesions, because no other imaging technique provides the same degree of sensitivity and specificity. It is also helpful in diagnosing uterine and ovarian factors.

Although laparoscopy is an invasion procedure and it requires general anaesthesia, it remains an essential part of the full assessment of infertile couple as it provides detailed anatomical and functional analysis of uterine and bilateral adnexa.

\section{METHODS}

Present study is a prospective observational study of laparoscopic finding in infertility cases at Panna Dhai Mahila Chikitsalaya, Udaipur, Rajasthan, India. This study was done for the duration of one year from January 2017 to December 2017. Present study included total 100 cases randomly selected attending obstetrics and gynecology, OPD with both primary and secondary infertility were included in present study. After taking detailed history, thorough clinical examination, investigations and informed consent diagnostic laparoscopy was done between $7^{\text {th }}$ to $11^{\text {th }}$ day of menses.

Under GA, diagnostic laparoscopy was done using laparoscope. During laparoscopy uterus, fallopian tube, ovaries, pouch of douglas and peritoneal cavity were thoroughly examined and evaluated. Treatment given according to peroperative finding and other responsible factors during laparoscopy polycystic ovarian drilling in cases of PCOD, chromopertubation for tubal patency, adhesiolysis etc, was done. Patient was discharged on the $2^{\text {th }}$ post-operative day according to her general condition and was followed on 5 th post-operative day for stitches removal.

\section{Inclusion criteria}

- All infertile patients (primary and secondary) who have undergone prior standard noninvasive investigation of infertility for both partners,

- Giving consent to undergo diagnostic laparoscopy for evaluation of the same.

\section{Exclusion criteria}

- Patients with absolute or relative contraindications for laparoscopy i.e., severe cardiopulmonary disease, presence of large abdominal masses, diaphragmatic hernia, bowel obstruction and gross obesity etc.,

- All those patients who hadn't gone prior standard noninvasive investigation of infertility,
- All those patients not willing to undergo diagnostic laparoscopy for evaluation.

The relevant details of all the women who were undergone diagnostic laparoscopy for infertility and satisfied the inclusion and exclusion criteria were recorded and the data was analyzed statistically using Descriptive statistics (frequency and percentage).

\section{RESULTS}

Present study included 100 patients of infertility. Out of them 62 patients were of primary infertility cases and 38 were of secondary.

The reduction in infertility and fecundity with advancing age has been well documented. In present study the most common age group of patients in between 26 to 30 years and amongst them $45 \%$ were with primary and secondary infertility, followed by age group in between 21 to 25 years was $43 \%$, followed by age group in between 18 to 20 years was $8 \%$ and one patients age was more than 35 years shown in (Table 1).

Table 1: Age wise distribution of cases.

\begin{tabular}{|lll|}
\hline Age group (years) & No. of cases & $\%$ of cases \\
\hline $18-20$ & 8 & 8 \\
\hline $21-25$ & 43 & 43 \\
\hline $26-30$ & 45 & 45 \\
\hline $31-35$ & 3 & 3 \\
\hline $36-40$ & 1 & 1 \\
\hline$>40$ & 00 & 00 \\
\hline Total & 100 & \\
\hline
\end{tabular}

In this study 81 cases, the duration of infertility was from 1 to 5 years. Amongst 81 cases primary infertility were 55 cases and secondary infertility were 26 cases. In 13 cases, the duration of infertility was from 6 to 10 years. Amongst 13 cases primary infertility were 4 cases and 9 cases were with secondary infertility. In 6 cases, the duration of infertility was from 10 to 15 years shown in (Table 2).

Table 2: Duration of infertility included in our cases.

\begin{tabular}{|llll|}
\hline Years & $\begin{array}{l}\text { Primary } \\
\text { infertility }\end{array}$ & $\begin{array}{l}\text { Secondary } \\
\text { infertility }\end{array}$ & Total \\
\hline $1-5$ & 55 & 26 & 81 \\
\hline $6-10$ & 4 & 9 & 13 \\
\hline $11-15$ & 3 & 3 & 6 \\
\hline Total & 62 & 38 & 100 \\
\hline
\end{tabular}

In present study most of the patients with infertility were asymptomatic that was $65 \%$. Irregular menstrual pattern was in $11 \%$ patients, followed by dyspareunia were in $8 \%$ cases and dysmenorrhoea were in 6\%cases. Other symptoms like white discharge and pelvic pain were $5 \%$ patients each shown in (Table 3 ). 
Table 3: Associated symptoms in women.

\begin{tabular}{|ll|}
\hline Symptomatic/asymptomatic & Number $(\mathbf{n}=100)$ \\
\hline Asymptomatic & $65 \%$ \\
\hline Irregular cycles & $11 \%$ \\
\hline Dysmenorrhea & $6 \%$ \\
\hline Dyspareunia & $8 \%$ \\
\hline White discharge & $5 \%$ \\
\hline Pelvic pain/ abdomen pain & $5 \%$ \\
\hline
\end{tabular}

\section{Laparoscopy findings}

In present study uterine findings detected on laparoscopy, $7 \%$ patients had fibroid uterus in which $3 \%$ patients from primary infertility and $4 \%$ from secondary infertility. Bulky uterus seen in $2 \%$ patients of primary infertility, arcuate uterus and hypoplastic uterus $1 \%$ was each from primary infertility shown in (Table 4).

Table 4: Uterine findings detected on laparoscopy.

\begin{tabular}{|lll|}
\hline Finding & $\begin{array}{l}\text { Primary } \\
\text { infertility }\end{array}$ & $\begin{array}{l}\text { Secondary } \\
\text { infertility }\end{array}$ \\
\hline Fibroid & $3 \%$ & $4 \%$ \\
\hline Arcuate uterus & $1 \%$ & - \\
\hline $\begin{array}{l}\text { Hypoplastic } \\
\text { uterus }\end{array}$ & $1 \%$ & - \\
\hline Bulky & $2 \%$ & - \\
\hline Normal & $55 \%$ & $34 \%$ \\
\hline
\end{tabular}

Ovarian findings in present study, 55\% women had ovarian pathology. In which $42 \%$ women had polycystic ovaries, $4 \%$ women had chocolate cyst of ovary, $5 \%$ women had simple ovaries cyst and 1\% women had haemorrhagic cyst shown in (Table 5).

Table 5: Ovarian findings.

\begin{tabular}{|ll|}
\hline Finding & $\begin{array}{l}\text { Number/percentage } \\
\mathrm{n}=100\end{array}$ \\
\hline Normal & $45(45)$ \\
\hline Polycystic ovary & $42(42)$ \\
\hline Chocolate cysts & $4(4)$ \\
\hline Embedded in adhesion & $1(1)$ \\
\hline Bald & $2(2)$ \\
\hline Ovarian cyst & 5 \\
\hline Hemorrhagic cyst & 1 \\
\hline
\end{tabular}

Table 6: Findings in pouch of Douglas.

\begin{tabular}{|ll|}
\hline Finding & Number/Percentage $\mathbf{n}=\mathbf{1 0 0}$ \\
\hline Adhesions & $7(7)$ \\
\hline Obliterated & $1(1)$ \\
\hline $\begin{array}{l}\text { Excessive fluid in } \\
\text { pouch of douglas }\end{array}$ & $16(16)$ \\
\hline Normal & $76(76)$ \\
\hline
\end{tabular}

In present study adhesion in pouch of douglas was seen in $7 \%$ patients, obliteration seen in $1 \%$ patients and excessive fluid in pouch of douglas were seen in $16 \%$ patients among them, straw colour of fluid in pouch of douglas due to tuberculosis and serous colour of fluid in pouch of douglas due to PID shown in (Table 6).

Table 7: Fallopian tube findings.

\begin{tabular}{|ll|}
\hline Finding & $\begin{array}{l}\text { Number/percentage } \\
(\mathrm{n}=100)\end{array}$ \\
\hline Normal & $67(67)$ \\
\hline Absent tube & $1(1)$ \\
\hline Peritubal adhesions & $6(6)$ \\
\hline Hydrosalpinx & $4(4)$ \\
\hline Beaded tubes & $5(5)$ \\
\hline Congested and inflamed tube & $9(9)$ \\
\hline Tuberculosis & $8(8)$ \\
\hline
\end{tabular}

In fallopian tube findings in present study, $67 \%$ patients had normal fallopian tube finding during laparoscopy and $33 \%$ patients had pathology in tube. Among them 9\% women had congested and inflamed tubes, followed by $8 \%$ women had tuberculoid tube, $5 \%$ had beaded tube, in $6 \%$ seen peri tubal adhesion and $4 \%$ women had hydrosalpinx shown in Table 7.

\section{DISCUSSION}

Diagnostic laparoscopy is now recognized as a basic skill which should be learnt by all gynecologists. It is an essential part of the complete evaluation of the infertile couple. Direct visualization of the abdominal and pelvic organs allows definitive diagnosis to be made where clinical evaluation and imaging techniques have failed or equivocal. It provides information regarding the uterine, ovarian pathology, tubal status and pelvic adhesions, biopsy specimen for histological confirmation. and has replaced certain old procedures like gas insufflations and even HSG in assessing the tubal patency. ${ }^{4}$ With advances in imaging techniques such as high-resolution Trans vaginal sonography, 3D ultrasound, saline infusion sonography, HSG, need of laparoscopy for diagnosis of infertility is reduced. However, in the same sitting diagnostic laparoscopy can be converted into therapeutic procedure thus offering definitive management for the infertile couple.

The present study, incidence infertility was $62 \%$ primary infertility and $38 \%$ secondary infertility cases. This is comparable to the other earlier studies of Kumar AK et al, where $64 \%$ had primary infertility and $36 \%$ had secondary infertility. ${ }^{5}$ Many studies in the literature have shown that there is rise in age at which women presented with infertility. It may be due to delayed marriage and child bearing. In present study mean age of infertility women was 26.2 years which is comparable to study by Talib W et al. ${ }^{6}$ 
In the present study uterine factors were found in $11 \%$ of the infertile patients. The studies conducted by Aziz $\mathrm{N}$ et al, Rai A et al, Chakraborty DK et al, found uterine factors in $6 \%, 11 \%$ and $14 \%$ respectively. Hence the results are comparable with the previous studies. ${ }^{7-9}$ In the present study ovarian pathology was seen in $55 \%$ of the women and among this $42 \%$ of the women had polycystic ovaries which is comparable to the study by Talib W et al. ${ }^{6}$ In present study anovulatory infertility is common. $33 \%$ of the women had tubal abnormalities detected on laparoscopy which correlates with the literature that tubal factors account for $15-30 \%$ of infertility. In present study $33 \%$ cases with either unilateral or bilateral tubal pathology out of which $4 \%$ had hydrosalpinx, $6 \%$ peri tubal adhesion, $14 \%$ women had bilateral block, $8 \%$ women had unilateral block. In similar study conducted by Foroozanfared $\mathrm{F}$ et al, showed bilateral patency $72.6 \%$ and unilateral or bilateral tubal block in $27.4 \% .{ }^{10}$ In similar study conducted by Mol BW et al. ${ }^{11}$ found that $6.04 \%$ had bilateral tubal occlusion and $5.69 \%$ had unilateral tubal occlusion whose findings were different from ours. In present study the incidence of endometriosis was $6 \%$ which is comparable to the studies of Sharma R et al, (6.6) and Chakraborty DK et al, (4.6\%). ${ }^{9-12}$ In the study by Naz $\mathrm{T}$ et al, the incidence of endometriosis was $10.29 \%$ in women with primary infertility. ${ }^{13}$ Pelvic inflammatory disease resulting in adhesions was seen in $8 \%$ of the women which is comparable with the study by Aziz $\mathrm{N}$ et al, (12\%). ${ }^{7}$ About $4 \%$ of the pelvic adhesions were found to be having pelvic tuberculosis on histopathology. This is comparable to the findings of Aziz N et al, $(6 \%)$ and Chakraborti DK et al, $(8.3 \%))^{7,9}$

\section{CONCLUSION}

Laparoscopy is a valuable technique for the complete assessment of female infertility, especially in symptomatic patients and should be used early in the diagnostic work up. With bulk of our patients belonging to low socio-economic status laparoscopic evaluation of infertile women offers therapeutic advantage to the needy infertile couple.

\section{ACKNOWLEDGMENTS}

Authors would like to thank D. P. Singh, Principal and Controller, R.N.T. Medical College and Associated Groups of Hospitals, Udaipur, Rajasthan, India. Dr. Sunita Maheshwari, Sr. Professor and Ex-Head, Department of Obstetrics and Gynaecology, Dr. Sushila Khoiwal, Dr.Sudha Gandhi, Dr. Gautam Damor and Dr. Radha Rastogi Professors, Dr. Bharat Bilwal, Dr. Alka Agarwal, Dr. Suman Sharma, Dr. Archana Bamaniya, Dr. Aditi Maurya, Dr. Renu Shashi, Dr. Rinku Sharma, Dr.
Prakash Jain,Dr. Sunita Shekhawat, Dr. Pallavi Sharma, Dr. Rachna Jain and Dr. Bhavna,Dr. Akanksha, Dr. Arihant Tater, Dr. Meenal Chugh, Dr. Swati, Dr. Kavita Gupta, Dr. Appoorva, Dr. Vidhi Goyal, Dr. Pradhuman, Dr. Mona, Dr. Rekha, Dr. Priyanka, Dr. Nitisha, Dr. Ravindra, Dr. Anita, Dr. Mitasha and Dr. Pramila.

Funding: No funding sources

Conflict of interest: None declared

Ethical approval: The study was approved by the Institutional Ethics Committee

\section{REFERENCES}

1. Ombelet W, Cooke I, Dyer S, Serour G, Devroey P. Infertility and the provision of infertility medical services in developing countries. Human Reproduct Update. 2008;14(6):605-21.

2. Speroff L, Glass RH, Kase NG,eds. Clinical gynecologic endocrinology and infertility. 7th ed. 2005;1013-67.

3. Jose Miller AB, Boyden JW, Frey KA. Infertility. Am Fam Physic. 2007;75:849-56.

4. Usmani AT. Laparoscopic evaluation of female infertility. Pak Arm Forces Med J. 1995;45(2):63-5.

5. Kumar AK. Diagnostic laparoscopy in the evaluation of female factor infertility Int J Reprod Contracept Obstet Gynecol. 2017 Feb;6(2):383-387.

6. Talib W, Ikram M, Hafeez M, Saeed M. Infertile female; laparoscopic evaluation. Professional Med J. 2007;14(4):562-6.

7. Aziz N. Laparoscopic evaluation of female factors in infertility. J Coll Physic Surg Pak. 2010;20(10):64952.

8. Rai A, Mishra MG. Diagnostic hystero-laparoscopy in work-up of female infertility. Int $\mathbf{J}$ Reprod Contracep, Obstetr Gynecol.2017;6(7):2853.

9. Chakraborti DK, Kole SK, Diagnostic laparoscopy in gynaecologic disorders. J Obst Gynecol. 1990;40:262-5.

10. Foroozanfard F, Sadat Z. Diagnostic value of hysterosalpingography and laparoscopy for tubal patency in infertile women. Nurs Midwifery Studies. 2013;2(2):188

11. Mol BW, Collins JA, Burrows EA, Van der Veen F, Bossuyt PM. Comparison of hysterosalpingography and laparoscopy in predicting fertility outcome. Human Reprod. 1999;14(5):1237-42.

12. Sharma R, Sharma V. The infertile women: a study of 120 cases. J Indian Med Assoc. 1991;89(2):31-2.

13. Naz T, Hassan L, Gulmeen, Nighat F, Sultan S. Laparoscopic evaluation in infertility. J Coll Physic Surg Pak. 2009;19(11):704.

Cite this article as: Shruti, Sen S. The prospective study of laparoscopic finding in infertility cases. Int $\mathbf{J}$ Reprod Contracept Obstet Gynecol 2019;8:2440-3. 